\title{
Teachers' Professional Development: A Content Analysis about the Tendencies in Studies
}

\author{
Nihal Yurtseven ${ }^{1}$, Mehtap Bademcioglu ${ }^{2}$ \\ ${ }^{1}$ School of Foreign Languages, Yildiz Technical University, Istanbul, Turkey \\ ${ }^{2}$ Graduate School of Social Sciences, Yildiz Technical University, Istanbul, Turkey \\ Correspondence: Nihal Yurtseven, School of Foreign Languages, Yildiz Technical University, 34210, Istanbul, Turkey
}

Received: March 22, 2016

Accepted: April 7, $2016 \quad$ Online Published: May 21, 2016

doi:10.11114/jets.v4i6.1475

URL: http://dx.doi.org/10.11114/jets.v4i6.1475

\begin{abstract}
The purpose of this study is to carry out a content analysis about the studies on teachers' professional development and to determine the tendencies in these studies. Within this scope, 60 studies that were registered to Turkish National Thesis Centre and ProQuest database between the years 2005-2015 were examined. Of the 60 studies, 37 of them were doctoral dissertations while 23 were written as master's theses. As part of the content analysis, the related studies were coded and categorized on a separate file according to certain variables. These variables were publication type, publication language, the year, field of research, research design, data collection tools, data analysis, the number of analyses, participant type, number of participants, average participant size, areas of study, findings, and recommendations. The data were analyzed through SPSS 20.0 software program. The results were presented as frequencies and percentages in a descriptive way. The findings of the current study indicated that the number of doctoral dissertations was more than the master theses and the $82 \%$ of the studies were written in English. Of the 60 studies on teachers' professional development, 20 of them were conducted in the years 2013-2014 and the most frequently used research design was qualitative research design. The most commonly used data collection technique was the interview while survey was the most frequently used data collection tool. The most frequently used sample type was teacher and the most frequently encountered sample size was $0-30$. On average, 78 participants took part in the studies while the minimum number was one and the maximum number was 1341. Lastly, the most frequently studied area was professional learning communities with a total number of 16 studies.
\end{abstract}

Keywords: professional development, content analysis

\section{Introduction}

Professional development is a dynamic process, which continues throughout a person's career and extends to receiving training, starting a profession, and retirement. Nicholls (2001) stated that a successful professional development depends on working conditions of teachers and how they perceive themselves within this framework. Professional development is critical for continuing the career of teachers. Blandford (2001) determined the primary aims of professional development as follows:

- To increase the range of teachers' implementations

- To meet the students' needs concertedly or individualistically by giving feedback about their experiences, researches and implementations

- To contribute to the school's professional life

- To keep the information about current educational practices alive

- To take into account the educational policy and try to raise standards

- To increase teachers' knowledge on society and communication technologies

According to Diaz-Maggioli (2004), professional development is a process that should continue throughout the career in which teachers may find opportunity to review their teaching and may learn how to meet the needs of students. Teachers have difficulty with updating their teaching practices and field knowledge in an educational institution where professional development is neglected. In this respect, Yildirim and Seker (2013) highlighted that supporting professional development and surrounding this development process with colleagues' cooperation are very important in educational institutions. 
Richards and Farrell (2005) implied that professional development can be established on two bases: corporate objectives and the teacher's personal goals. They can be carried out collectively. In professional development studies, if the teachers' personal development is prioritized, the following areas of professional development can be included to the process:

- Pedagogical content knowledge: It focuses on any specific issue on teachers' branch (e.g. grammar teaching, discourse analysis, methodology, and program development).

- Pedagogical expertise: It concentrates on attention toward teachers' learning about a new subject area and improving their existing knowledge.

- Self-consciousness: It is centered upon teacher's knowing herself/himself as a teacher and exploring her/his strengths and weaknesses.

- Understanding learners: It is mainly related to teachers' recognizing the problems and difficulties experienced by learners and how to make the content more accessible for everyone.

- Curriculum and material: It focuses on teachers' recognizing and developing of curriculum, alternatives, and teaching materials.

- Career development: It lays emphasis on the development of teachers' knowledge, area of expertise, and mentoring and supervising skills for career development and promotion.

Professional development process where understanding is the focal point and is focused on how students learn is an issue that should be emphasized strongly in all branches (National Board for Professional Teaching Standards, 2002; Shulman \& Sparks, 1992). The main constituents of an effective professional development model are: being prepared clearly through the goals and objectives according to the needs of teachers and students (Birman, Desimone, Porter, \& Garet, 2000; Desimone, 2009); sparing enough time for teachers to think about the subject (Birman et al., 2000; Garet, Porter, Desimone, Birman, \& Yoon, 2001; Ingvarson, Meiers, \& Beaviset, 2005); and being suitable to receive feedback and a convenient structure for cooperation (Darling-Hammond \& McLaughlin, 1995; Ingvarson et al., 2005; Joyce \& Showers, 2002; Lieberman \& Pointer, 2008).

This study is significant in the sense that it depicts the inclination in the studies written on teachers' professional development. In addition, the scarcity of the content analysis studies about this field increases the relevance of this study. Within this framework, the purpose of this study is to carry out a content analysis about the studies on teachers' professional development and to determine the tendencies in this respect. The research questions are as follows:

1. What is the distribution of studies carried out between 2005 and 2015 on teachers' professional development with regard to the publication type?

2. What is the distribution of studies carried out between 2005 and 2015 on teachers' professional development with regard to the language?

3. What is the distribution of studies carried out on teachers' professional development with regard to the year of publication?

4. What is the distribution of studies carried out between 2005 and 2015 on teachers' professional development with regard to the research design?

5. What is the distribution of studies carried out between 2005 and 2015 on teachers' professional development with regard to data collection techniques?

6. What is the distribution of studies carried out between 2005 and 2015 on teachers' professional development with regard to data collection tools?

7. What is the distribution of studies carried out between 2005 and 2015 on teachers' professional development with regard to the number of sources of data?

8. What is the distribution of studies carried out between 2005 and 2015 on teachers' professional development with regard to the sample?

9. What is the distribution of studies carried out between 2005 and 2015 on teachers' professional development with regard to the sample size?

10. What is the distribution of studies carried out between 2005 and 2015 on teachers' professional development with regard to the analysis type?

11. What is the distribution of studies carried out between 2005 and 2015 on teachers' professional development with regard to the average number of participants?

12. What is the distribution of studies carried out between 2005 and 2015 on teachers' professional development with regard to the areas of study?

13. What is the distribution of studies carried out between 2005 and 2015 on teachers' professional development with regard to the findings? 
14. What is the distribution of studies carried out between 2005 and 2015 on teachers' professional development with regard to the recommendations?

\section{Method}

\subsection{Research Design}

The study was carried out through content analysis. The content analysis is the analysis of relatively unstructured data within certain meanings, symbolic qualities, and expressive contents (Krippendorff, 2004). It helps to identify patterns and themes in a detailed and systematic way (Berg \& Lune, 2012). To do so, the researcher follows a four-step path as coding the data, finding the themes, classification of codes and themes, and identifying findings / interpretation (Yildirim \& Simsek, 2008).

\subsection{Data Collection Process}

The study started through the investigation of studies on teachers' professional development via two databases: Turkish National Thesis Centre and ProQuest database. The studies encountered were randomly chosen and saved on a Google Drive file so that both researchers had proper access to the studies chosen. Within the scope of the study, 37 doctoral dissertations and 23 master theses were gained from the databases. Each study was listed on a Microsoft Excel page and coded under the identified themes.

\subsection{Data Analysis}

As part of the data analysis, 13 themes were identified: (1) Language, (2) year of publication, (3) research design, (4) data collection techniques, (5) data collection tools, (6) number of sources of data, (7) sample, (8) sample size, (9) analysis type, (10) average number of participants, (11) area of study, (12) findings, and (13) recommendations. Each theme had some categories and they can be seen on Table 1 .

As can be seen in Table 1, each theme had at least two categories. The study started by examining the studies and coding data into the relevant column in Excel file. After the researchers completed coding and categorizing, they started analyzing the data through SPSS 20.0 software program and they used clustered columns to visualize what they found in the findings part. 
Table 1. Research themes and categories

\begin{tabular}{|c|c|}
\hline Themes & Categories \\
\hline Publication Type & $\begin{array}{ll}\bullet & \text { Master's Thesis } \\
- & \text { Doctoral Dissertation }\end{array}$ \\
\hline Language & $\begin{array}{ll}- & \text { Turkish } \\
- & \text { English } \\
\end{array}$ \\
\hline Year of Publication & - $\quad 2005,2006,2007,2008,2009,2010,2011,2012,2013,2014,2015$ \\
\hline Research Design & $\begin{array}{ll} & \text { Quantitative Design } \\
- & \text { Qualitative Design } \\
- & \text { Mixed Method Design } \\
\end{array}$ \\
\hline Data Collection Techniques & $\begin{array}{ll} & \text { Interview } \\
: & \text { Observation } \\
- & \text { Document Analysis } \\
& \text { Field Notes } \\
\end{array}$ \\
\hline Data Collection Tools & $\begin{array}{ll} & \text { Survey } \\
& \text { Academic Achievement Scores } \\
& \text { Test / Quiz } \\
\end{array}$ \\
\hline Number of Sources of Data & $\begin{array}{ll}- & \text { One Sources of Data } \\
- & \text { Two Sources of Data } \\
& \text { Three or More Sources of Data } \\
\end{array}$ \\
\hline Sample & $\begin{array}{ll} & \text { Teacher } \\
- & \text { Student } \\
\text { - } & \text { Administrator } \\
& \text { Academician } \\
\end{array}$ \\
\hline Sample Size & $\begin{array}{ll} & 0-30 \\
: & 31-50 \\
: & 51-100 \\
: & 101-250 \\
& 251-500 \\
& 501+\end{array}$ \\
\hline Analysis Type & $\begin{array}{ll}- & \text { Descriptive } \\
- & \text { Predictive } \\
- & \text { Qualitative } \\
\end{array}$ \\
\hline Average Number of Participants & $\begin{array}{ll}\bullet & \text { Minimum } \\
\bullet & \text { Maximum } \\
- & \text { Average } \\
\end{array}$ \\
\hline Area of Study & $\begin{array}{ll}\text { - } & \text { Professional Learning Communities } \\
\text { - } & \text { Characteristics of Effective PD Programs } \\
\text { - } & \text { Comparional Coaching of Different Countries } \\
\text { - } & \text { Factors Affecting Teachers' Participation in PD } \\
\text { - } & \text { Pre-service Education } \\
\text { - } & \text { Reflective Teaching } \\
\text { Strategies for PD } \\
\text { - } & \text { Teachers PD Needs } \\
\text { - } & \text { The Rolect of a PD Program } \\
\end{array}$ \\
\hline Findings & $\begin{array}{ll} & \text { Different countries' PD practices } \\
\text { - } & \text { The need to change the structure of PD activities } \\
\text { - } & \text { Administrators' role in PD } \\
\text { - } & \text { Pailoring PD activities according to teachers' needs } \\
\text { - } & \text { Positive attitude for PD } \\
\text { - } & \text { Teacher leaders have a significant role in teachers' PD experiences } \\
\text { - No positive relationship between PD activities and improved teacher practice } \\
\text { - PD \& Student learning relationship } \\
\text { Positive relationship between PD activities and improved teacher practice } \\
\text { PD activities have positive effects on teachers' PD }\end{array}$ \\
\hline Recommendations & 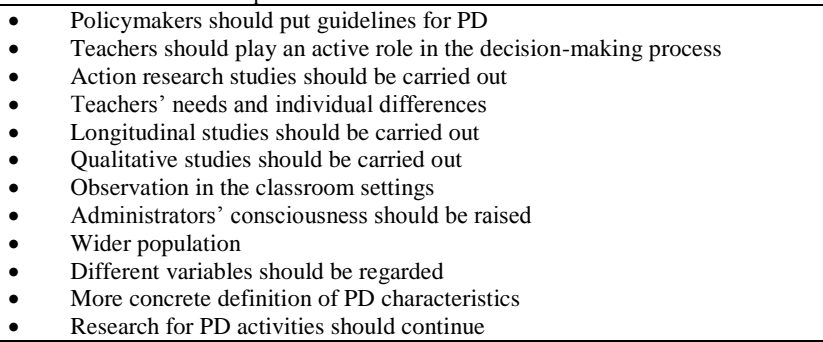 \\
\hline
\end{tabular}

\subsection{Validity and Reliability of the Study}

For the validity and reliability of the study, the researchers paid utmost importance to having consensus about finding themes, categories, and coding data properly. After completing data, both researchers examined data once again in order to make sure that the data was coded appropriately. Furthermore, the codes, categories, and themes were checked by two experts in the field of teacher education. 


\section{Results}

3.1 The Distribution of Studies Carried out between 2005 and 2015 on Teachers' Professional Development with Regard to the Publication Type

With regard to the first research question, the publication type of the studies was examined and the results were presented in Figure 1:

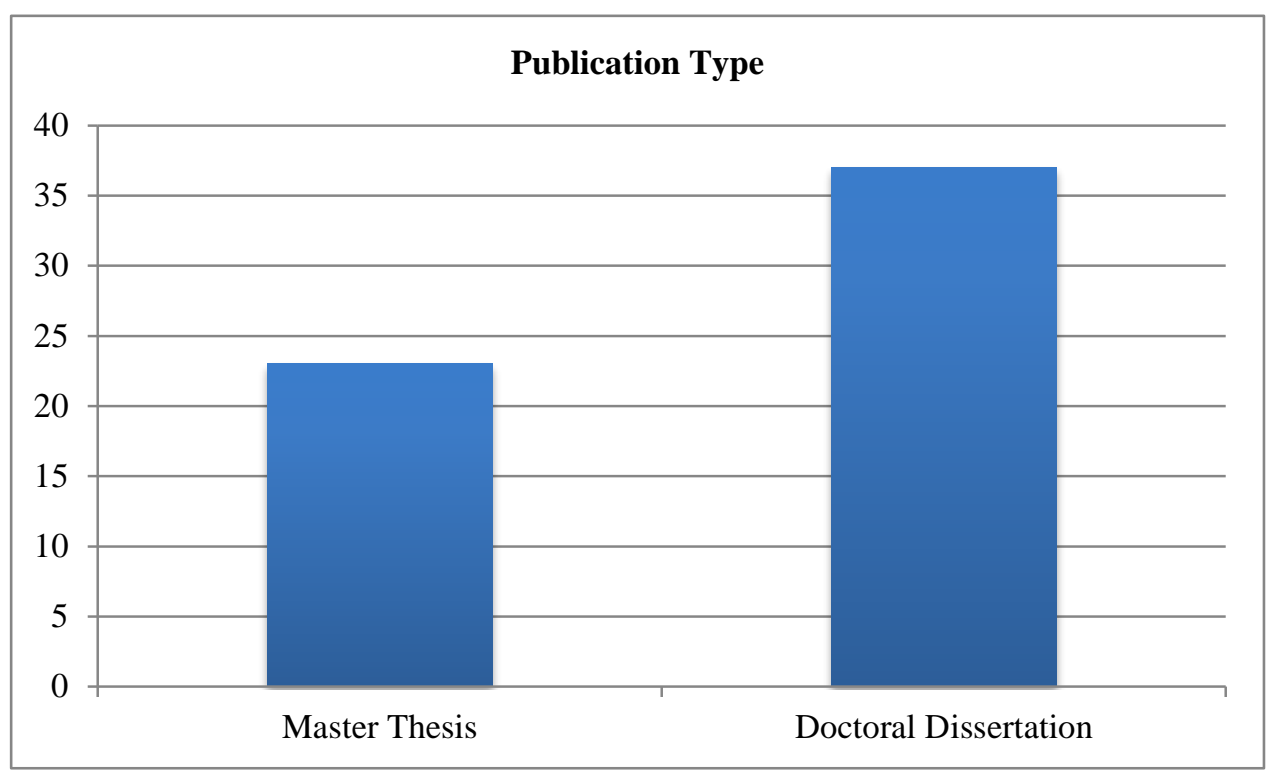

Figure 1. The distribution of studies carried out between 2005 and 2015 on teachers' professional development with regard to the publication type

According to the results which can be seen in Figure 1, only master theses and doctoral dissertations were included in the scope of the study. Of the 60 studies, 23 of them were master theses and 37 of them were doctoral dissertations.

3.2 The Distribution of Studies Carried out between 2005 and 2015 on Teachers' Professional Development with Regard to the Language

With regard to the second research question, the publication language of the studies was examined and the results were presented in Figure 2.

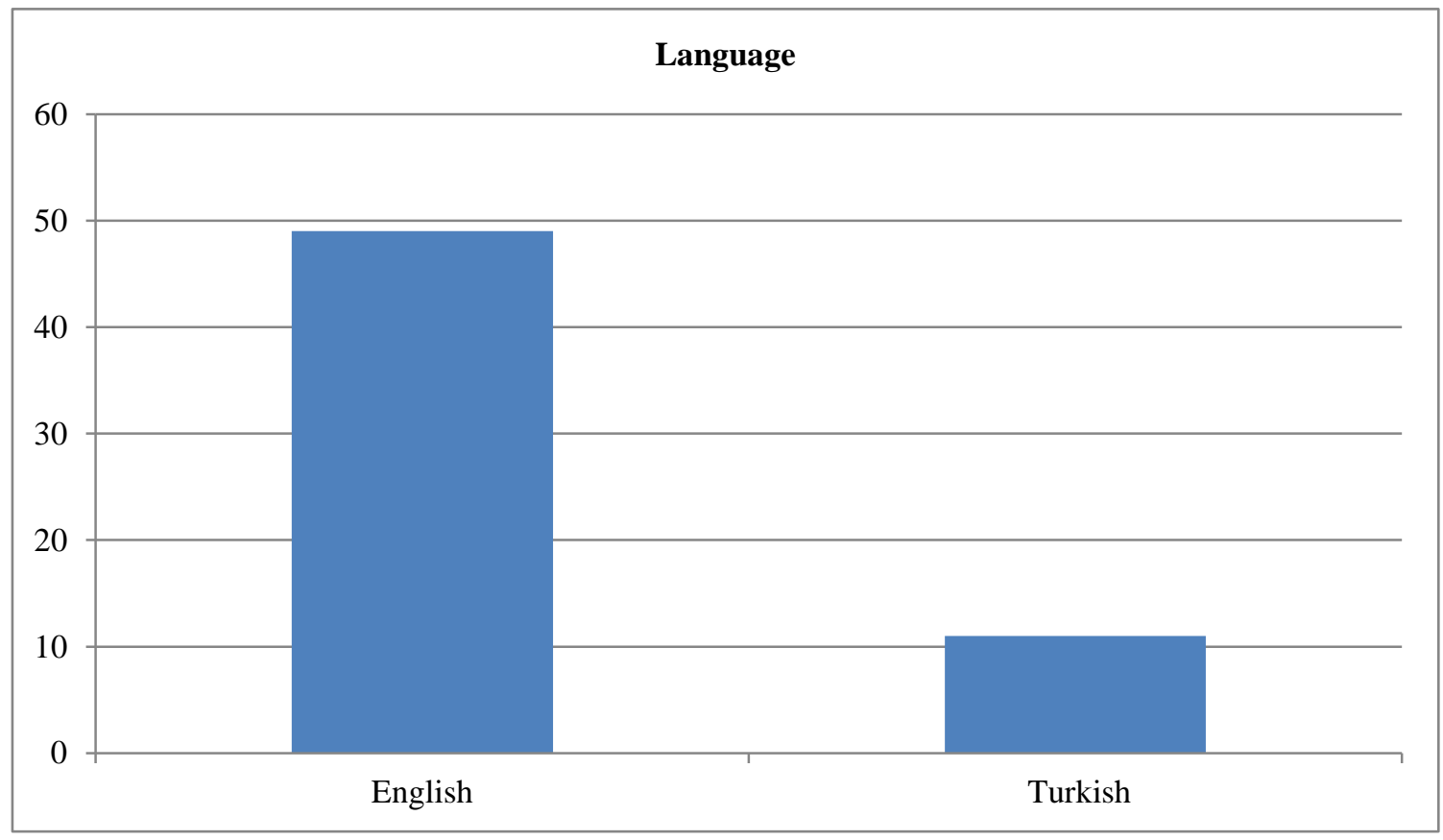

Figure 2. The distribution of studies carried out between 2005 and 2015 on teachers' professional development with regard to the language 
As can be seen in Figure 2, of the 60 studies, $49(82 \%)$ of them were English while 11 (18\%) of them were written in Turkish.

3.3 The Distribution of Studies Carried out between 2005 and 2015 on Teachers' Professional Development with Regard to the Years

Professional development is an issue that has been studied over the last thirty years. However, the popularity of the topic has increased with the new century, and in the current study, only the last ten years of the literature was investigated as part of the content analysis. The number of studies can also be examined in Figure 3:

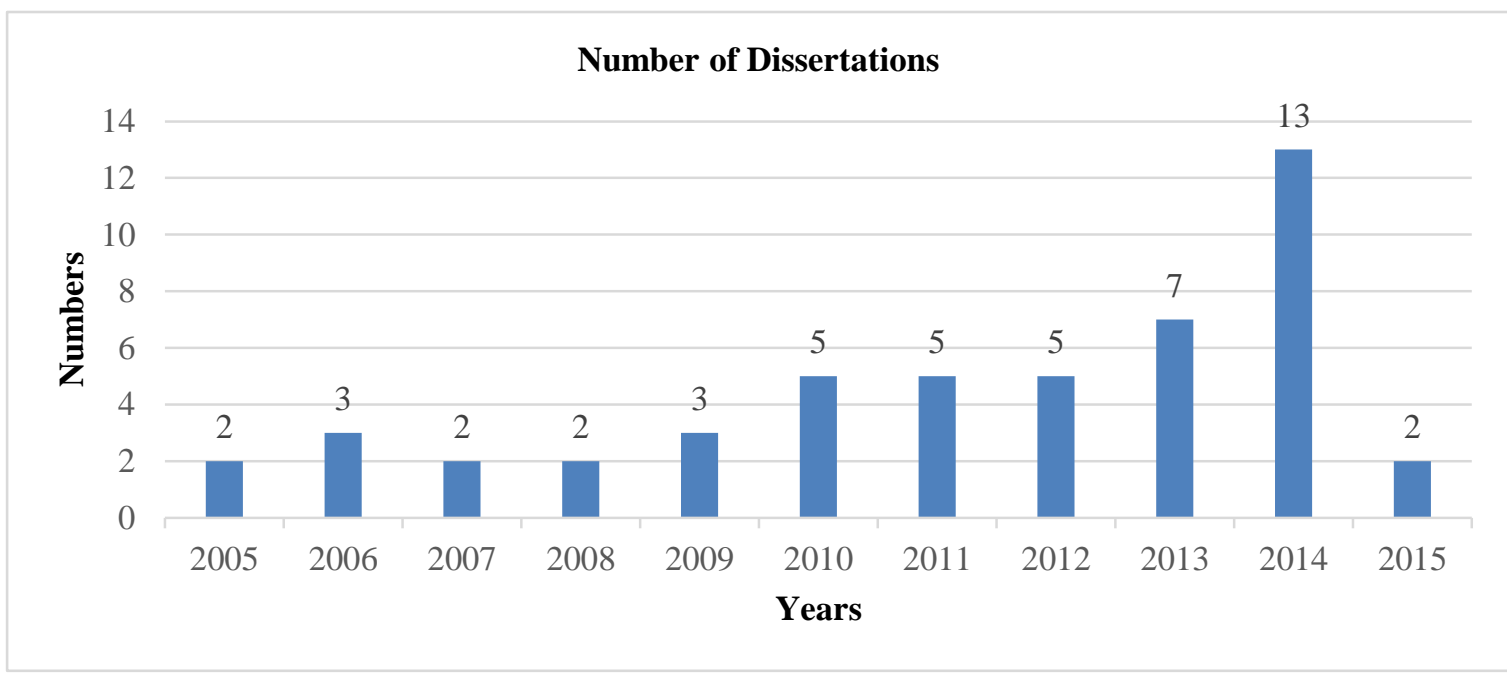

Figure 3. The distribution of studies carried out between 2005 and 2015 on teachers' professional development with regard to the years

3.4 The Distribution of Studies Carried out between 2005 and 2015 on Teachers' Professional Development with Regard to the Research Design

Across the studies that were examined within the scope of the study, three main research design models were met; namely, quantitative, qualitative, and mixed method design. The distribution of the studies was presented in Figure 4:

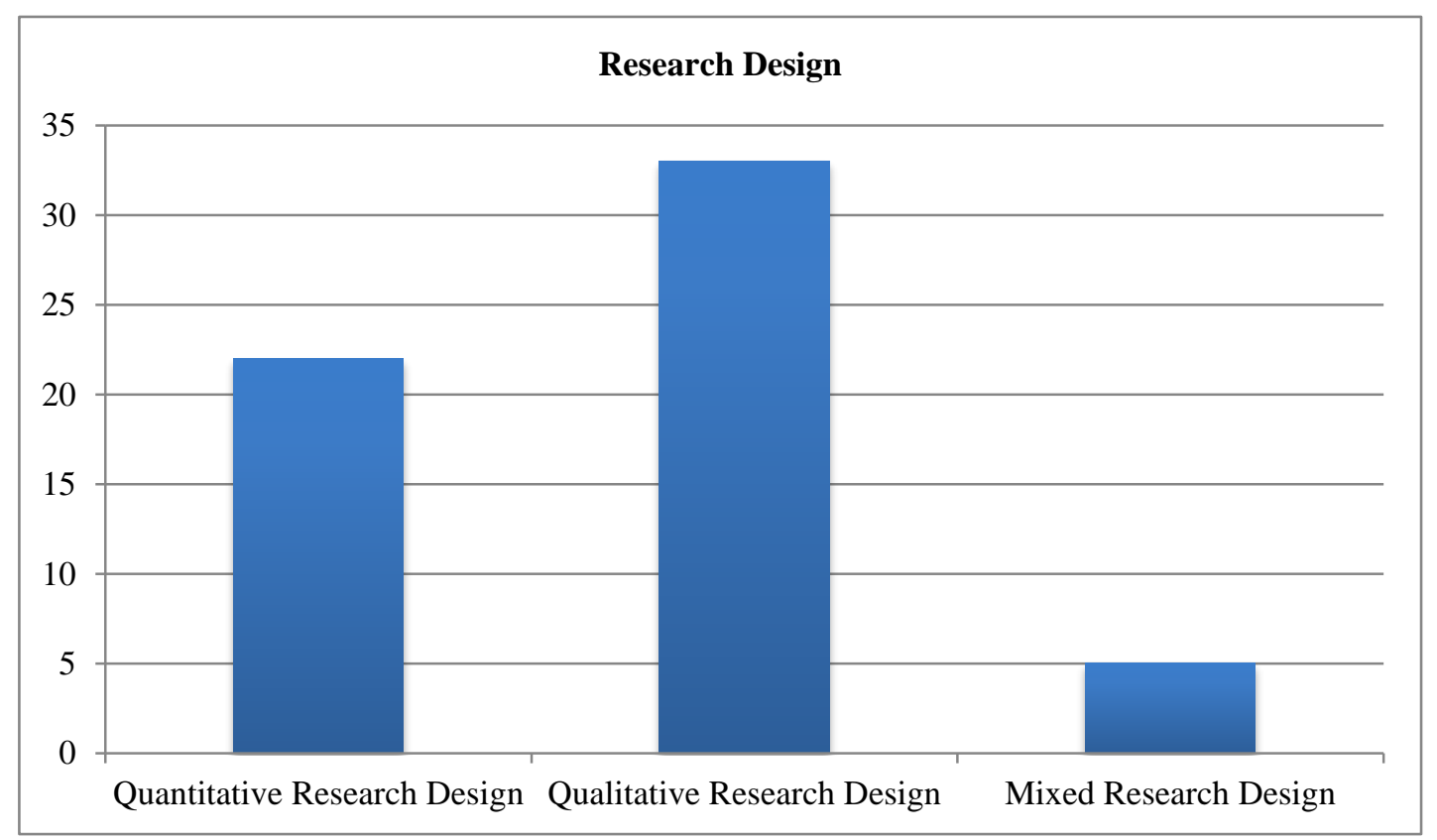

Figure 4. The distribution of studies carried out between 2005 and 2015 on teachers' professional development with regard to the research design

As it is presented in Figure 4, the most frequently used research design was qualitative research design. Quantitative 
research design was in the second rank and mixed research design was the least frequently used one. On the other hand, 22 of the studies were carried out through quantitative research design, while 33 of them had qualitative and five of them had mixed research design.

3.5 The Distribution of Studies Carried out between 2005 and 2015 on Teachers' Professional Development with Regard to Data Collection Techniques

Three main data collection techniques were instrumented in the studies that were examined. They were namely the interview, the document analysis, and the observation. The distribution of the studies according to data collection techniques is was presented in Figure 5:

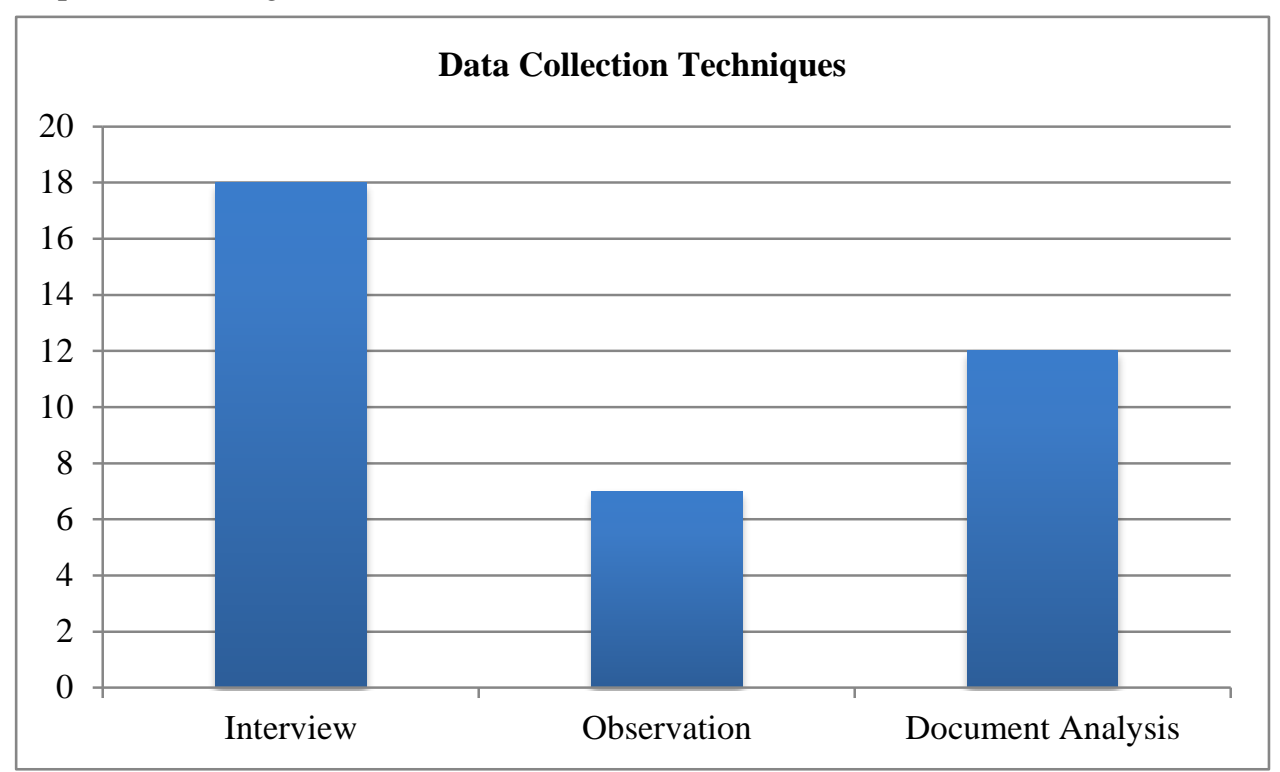

Figure 5. The distribution of studies carried out between 2005 and 2015 on teachers' professional development with regard to data collection techniques

As can be seen in Figure 5, the most frequently used data collection technique was the interview, which was used in 18 studies. The second frequently used technique was the document analysis, with a number of 12 studies. The observation was the least frequently used data collection technique, which was used in 7 studies.

3.6 The Distribution of Studies Carried out between 2005 and 2015 on Teachers' Professional Development with Regard to Data Collection Tools

Three main data collection tools were met throughout the content analysis. They were survey, academic achievement scores, and tests/quizzes. The distribution of the studies according to data collection tools was presented in Figure 6:

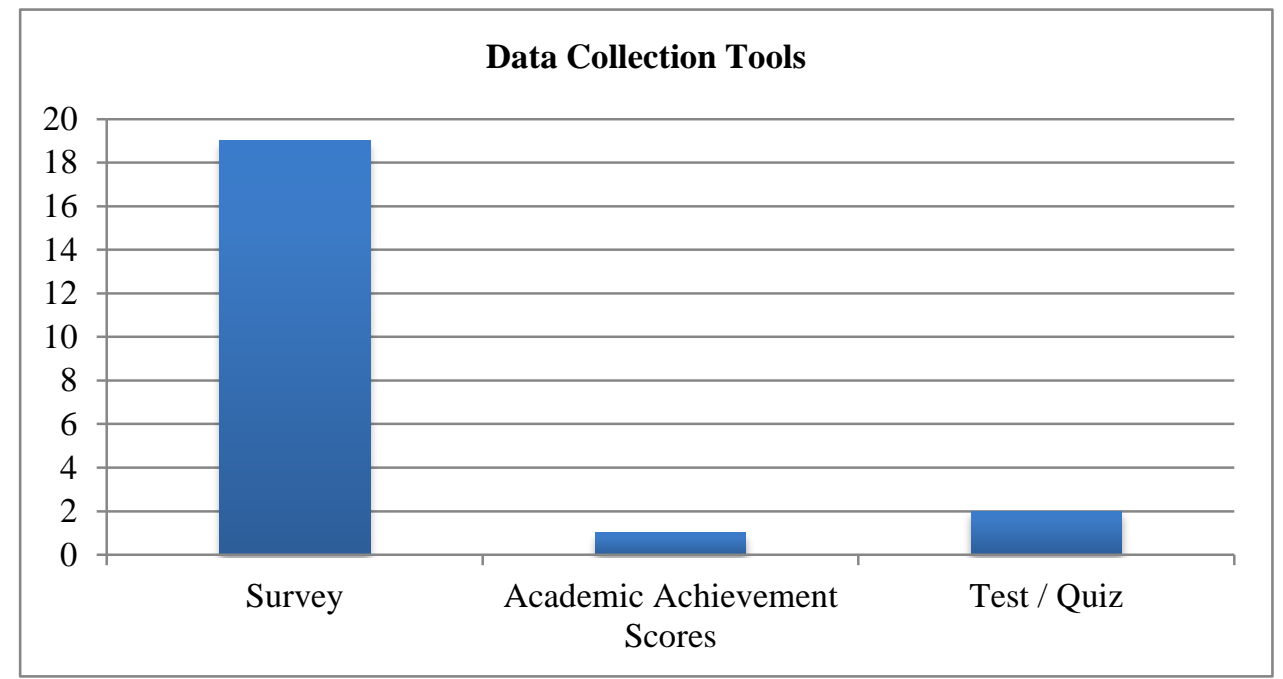

Figure 6. The distribution of studies carried out between 2005 and 2015 on teachers' professional development with regard to data collection tools 
As presented in Figure 6, the most frequently used data collection tool was the survey, which was used in 19 studies. Academic achievement scores were used only in one dissertation and test/quiz was instrumented in two studies.

3.7 The Distribution of Studies Carried out between 2005 and 2015 on Teachers' Professional Development with Regard to the Number of Sources of Data

In the studies that were examined, the number of the sources of data was also examined. There were studies that were carried out through the instrumentation of one source of data, two sources of data, and more than two sources of data. The distribution of the studies according to data analysis type was presented in Figure 7:

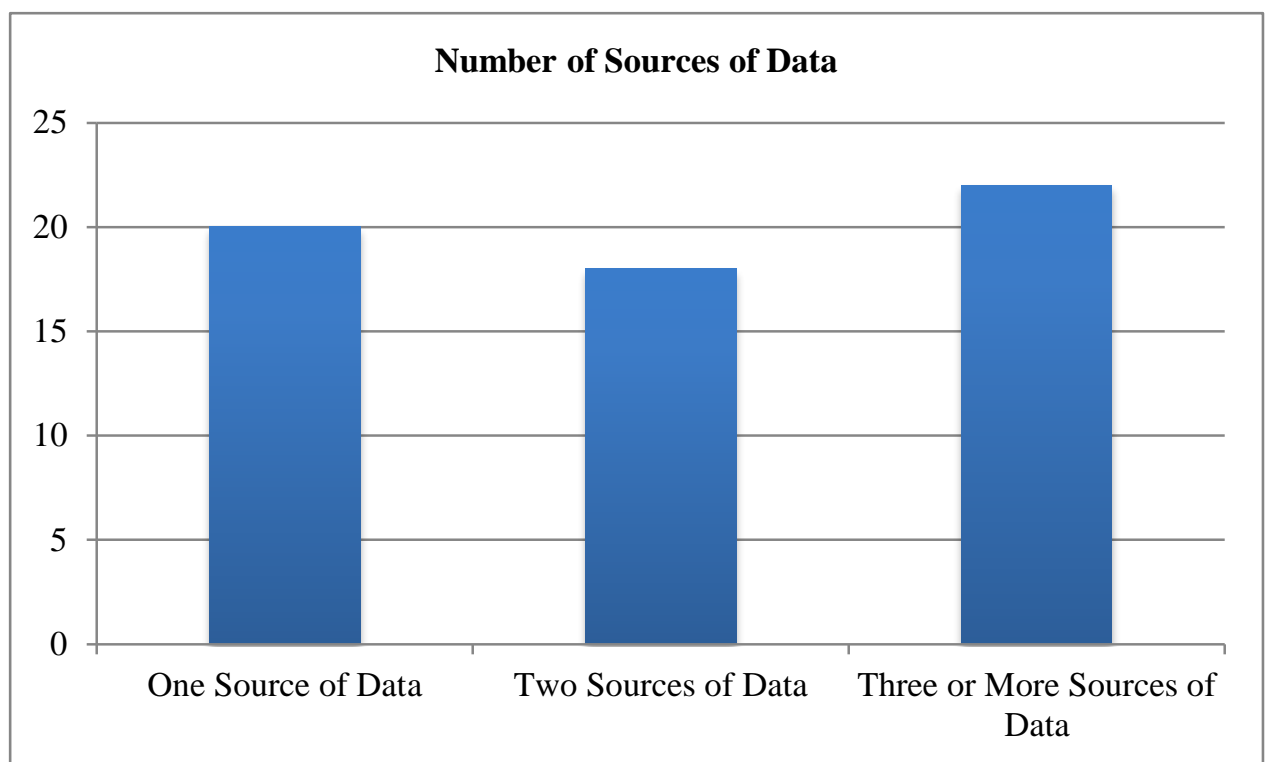

Figure 7. The distribution of studies carried out between 2005 and 2015 on teachers' professional development with regard to the number of sources of data

When Figure 7 is examined, it can be seen that the number of the sources of data were near each other. One source of data was used in 20 studies while two sources of data were used in 18 studies. The number of studies in which three or more sources of data were used was 22.

3.8 The Distribution of Studies Carried out between 2005 and 2015 on Teachers' Professional Development with Regard to the Sample

When the sample of the studies was examined, a wide range of combinations were come across. The distribution of the studies according to sample was presented in Figure 8: 


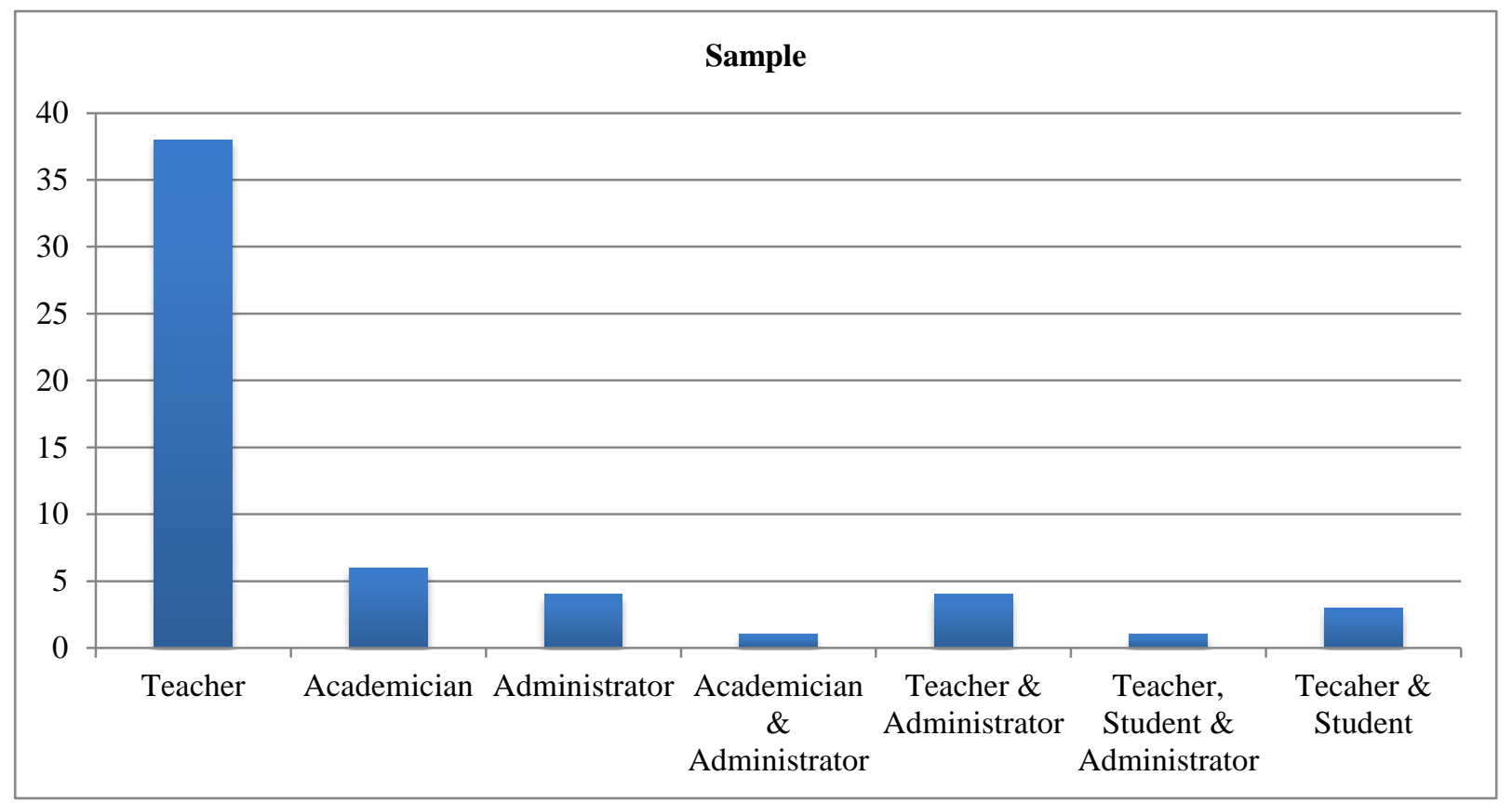

Figure 8. The distribution of studies carried out between 2005 and 2015 on teachers' professional development with regard to the sample

As can be seen in Figure 8, the most frequently used sample type was teacher. In 38 of the studies, teachers were used as sample. In 6 of the studies, academicians constituted the sample of the studies. In four of the studies, administrators were referred to as sample. Furthermore, combinations of samples were used in some studies. For instance, in one dissertation, academicians and administrators were used. Teacher and administrator combination were encountered in four studies. In one of the studies the combination of teacher, student, and administrator was used. Lastly, teacher and student combination was used in three of the studies.

\subsection{The Distribution of Studies Carried out between 2005 and 2015 on Teachers' Professional Development with} Regard to the Sample Size

The studies that were examined had six type of sample size; 0-30, 31-50, 51-100, 101-250, 251-500, and more than 500. The distribution of the studies according to sample size was presented in Figure 9:

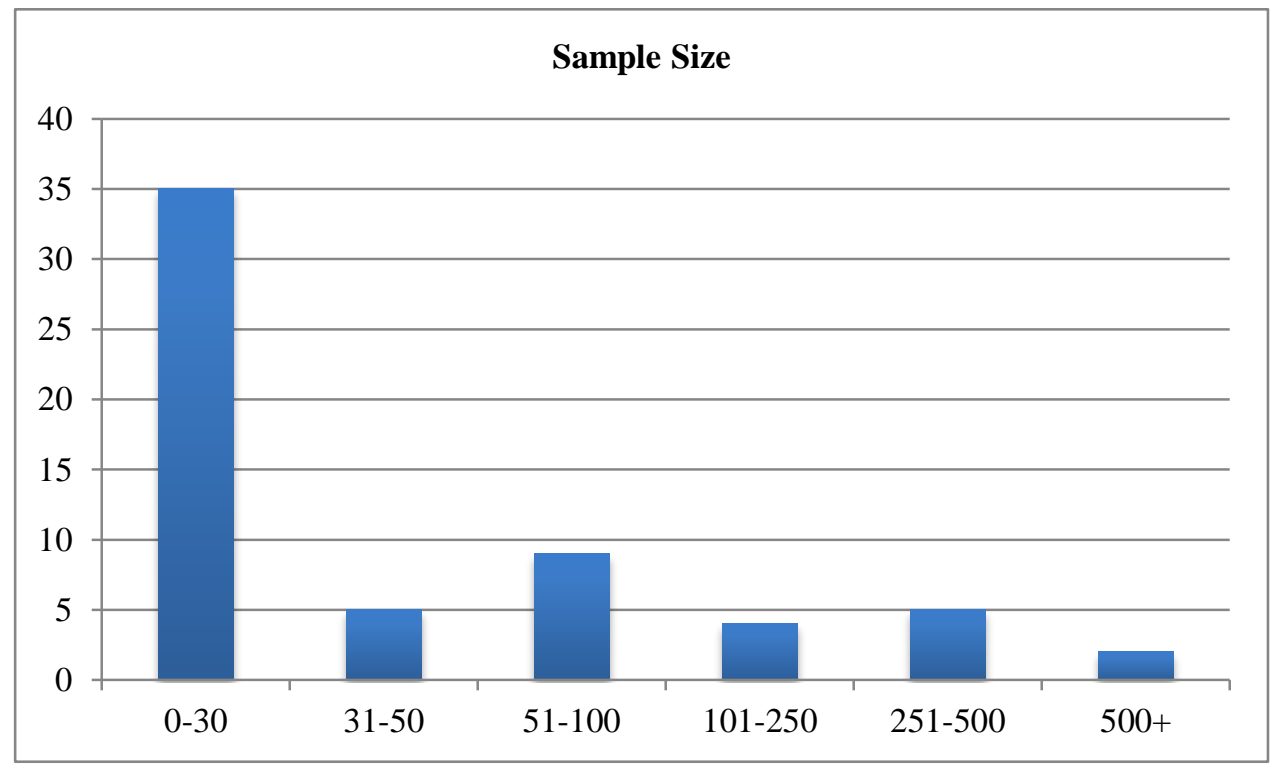

Figure 9. The distribution of studies carried out between 2005 and 2015 on teachers' professional development with regard to the sample size

When Figure 9 is examined, it can be seen that the most frequently encountered sample size was 0-30. 35 of the studies were carried out with a sample size ranging between $0-30$. There were five studies carried out with a sample size of 
31-50. Nine of the studies were carried out with 51-100 participants. Four studies were carried out with a sample size of 101-250. Five studies used a sample size of 251-500. In two of the studies more than 500 participants took part.

3.10 The Distribution of Studies Carried out between 2005 and 2015 on Teachers' Professional Development with Regard to the Analysis Type

The types of the analyses in the studies that were examined had a wide range. The types of analyses were presented in Figure 10:

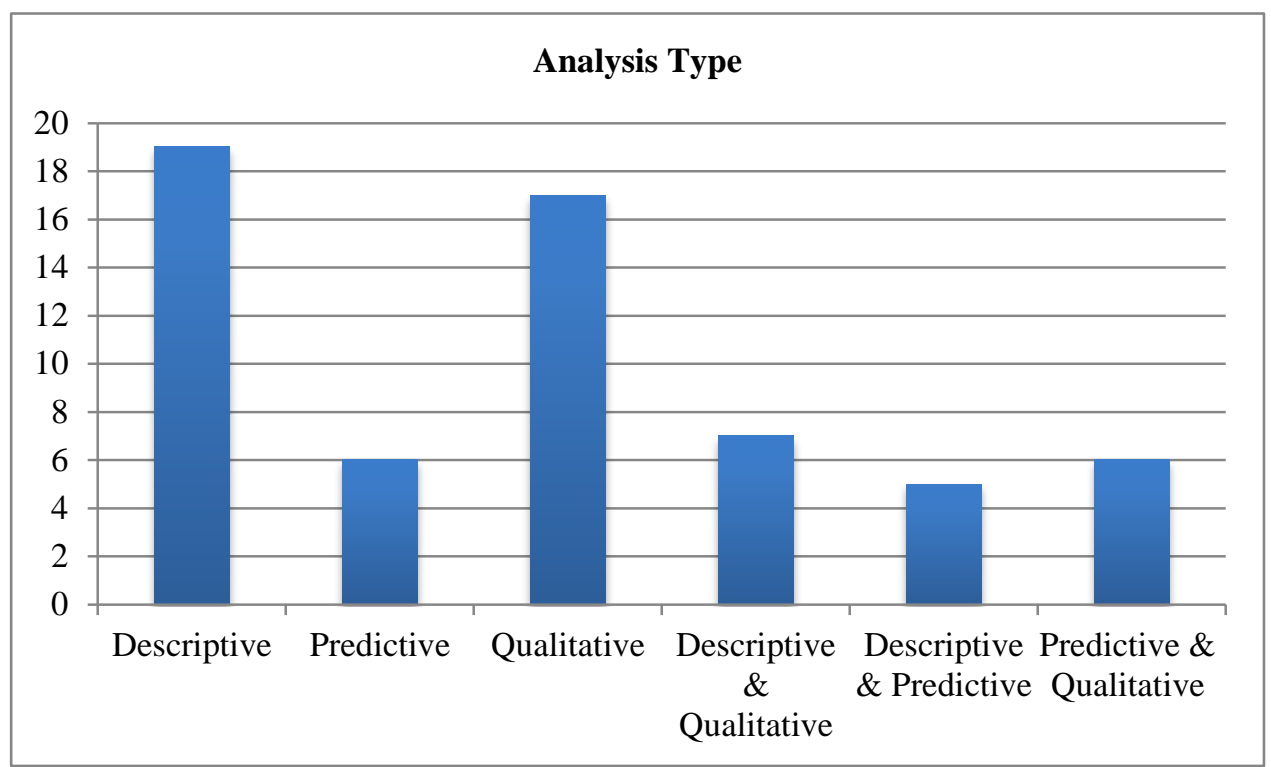

Figure 10. The distribution of studies carried out between 2005 and 2015 on teachers' professional development with regard to the analysis type

In accordance with the results that can be seen in Figure 10 there were mainly three types of analysis type; namely, descriptive, predictive, and qualitative. However, they were either used solely or by combining two of them in the studies. Descriptive $(n=19)$ and qualitative $(n=17)$ analyses were the most frequently used analysis types in the studies. In addition, six of the studies included predictive analysis. As a combination, seven studies contained descriptive and qualitative analysis, five of them included descriptive and predictive analysis, and six of the studies instrumented predictive and qualitative analyses in their format.

3.11 The Distribution of Studies Carried out between 2005 and 2015 on Teachers' Professional Development with Regard to the Average Number of Participants

The distribution of the studies according to the number of participants was presented in Figure 11:

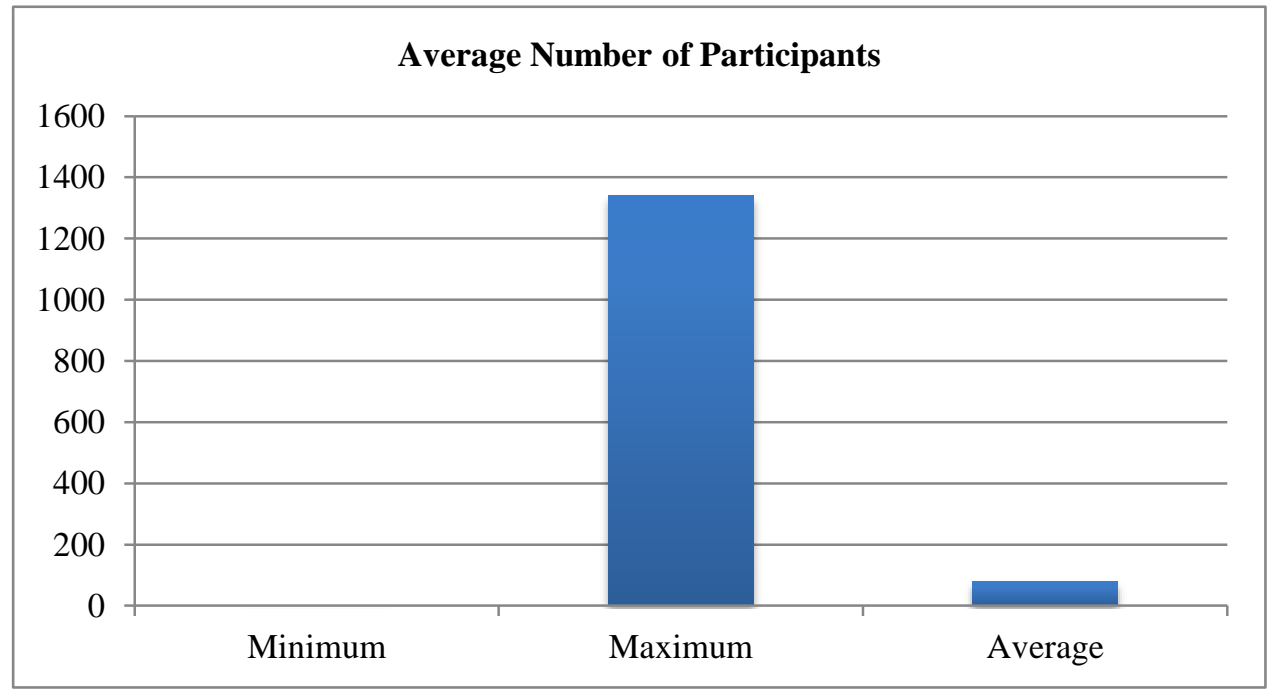

Figure 11. The distribution of studies carried out between 2005 and 2015 on teachers' professional development with regard to the average number of participants 
As can be seen in Figure 11, the maximum number of participants in the studies was 1341 while the minimum number was one. On average, 78 participants took part in the studies.

3.12 The Distribution of Studies Carried out between 2005 and 2015 on Teachers'Professional Development with Regard to the Areas of Study

The studies that were examined had a wide range of areas of study. The distribution of the areas of studies can be found in Figure 12:

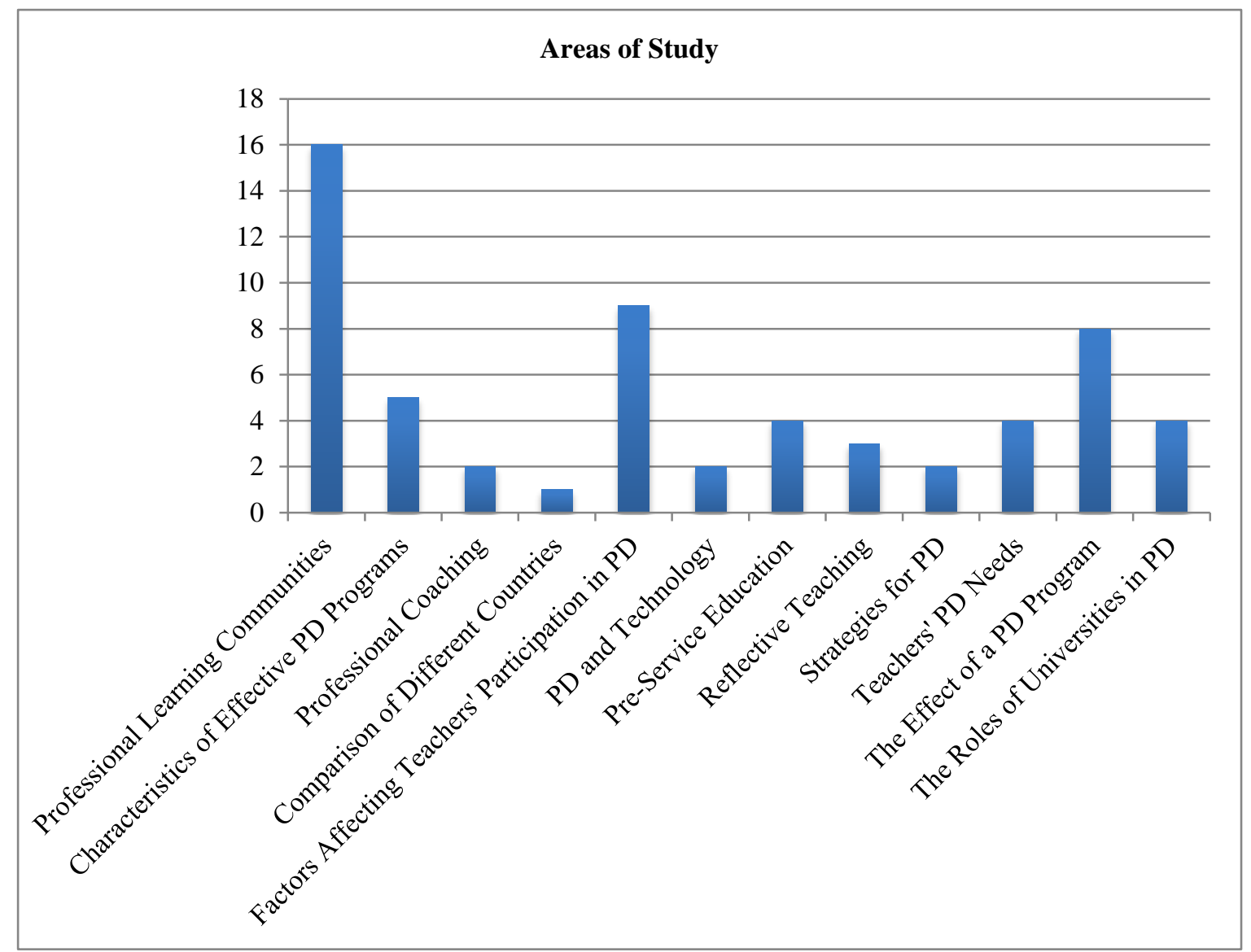

Figure 12. The distribution of studies carried out between 2005 and 2015 on teachers' professional development with regard to the areas of study

As it is presented in Figure 12, the most frequently studied area is professional learning communities with total number 16 studies. Factors affecting teachers' participation in professional development was studied in nine studies while the effect of a professional development program was studied in eight studies.

3.13 The Distribution of Studies Carried out between 2005 and 2015 on Teachers' Professional Development with Regard to the Findings

A variety of findings were encountered when the studies were analyzed. The distribution of the findings was presented in Figure 13: 


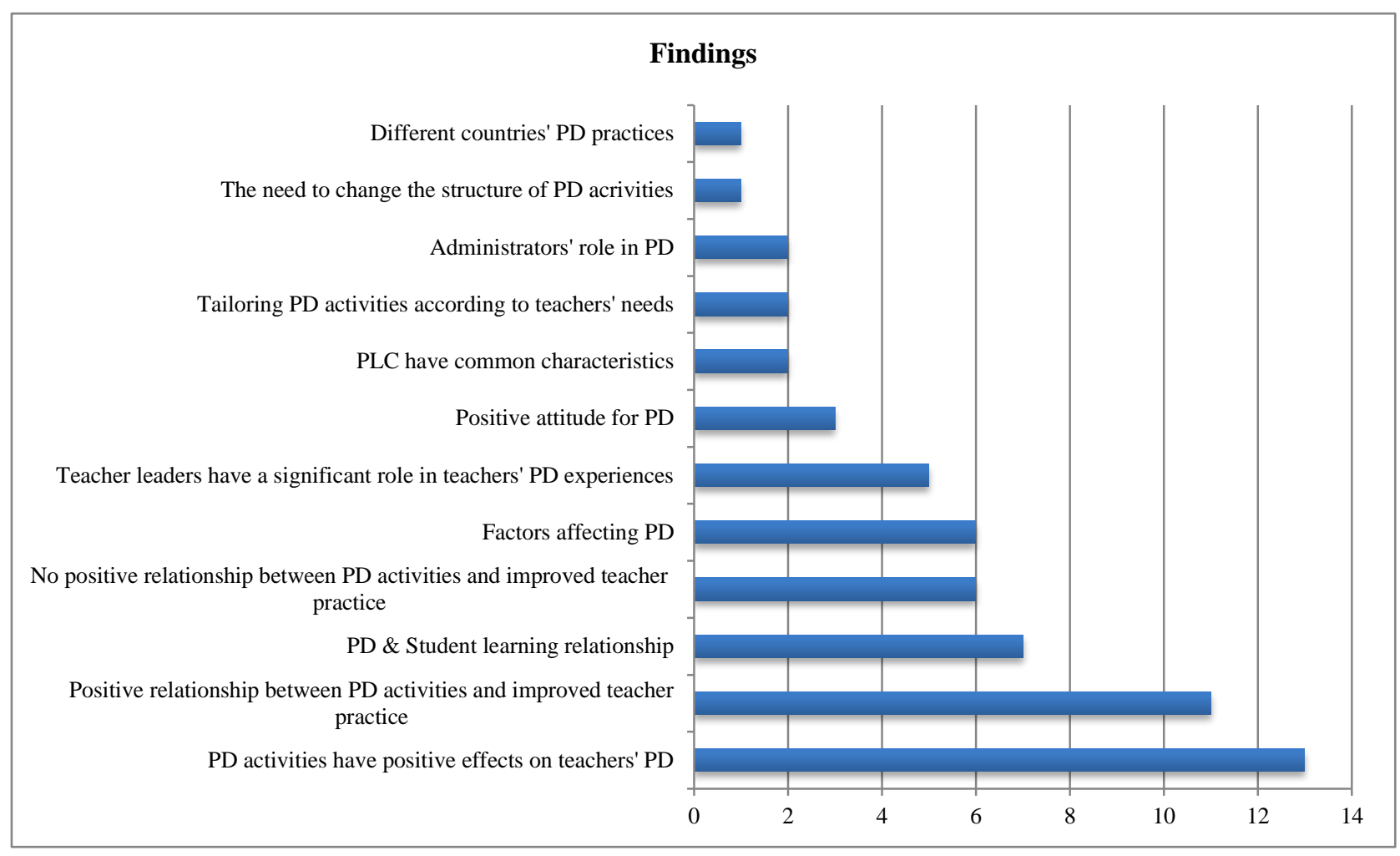

Figure 13. The distribution of studies carried out between 2005 and 2015 on teachers' professional development with regard to the findings

In 13 of the studies it was found out that PD activities had positive effects on teachers' professional development, as it can be seen in Figure 13. Positive relationship between professional development activities and improved teacher practice was found in 11 studies while there was a relationship between professional development and student learning in seven of the studies. It was mentioned that there was no relationship between professional development activities and improved teacher practice in six of the studies and factors affecting professional development were identified in six studies. Other findings were about teacher leaders' and administrators' roles in professional development, tailoring activities according to teachers' needs, the need to change the structure of professional development activities and implementations in different countries.

3.14 The Distribution of Studies Carried out between 2005 and 2015 on Teachers' Professional Development with Regard to the Recommendations

A variety of recommendations were encountered when the studies were analyzed. The distribution of the recommendations was presented in Figure 14: 


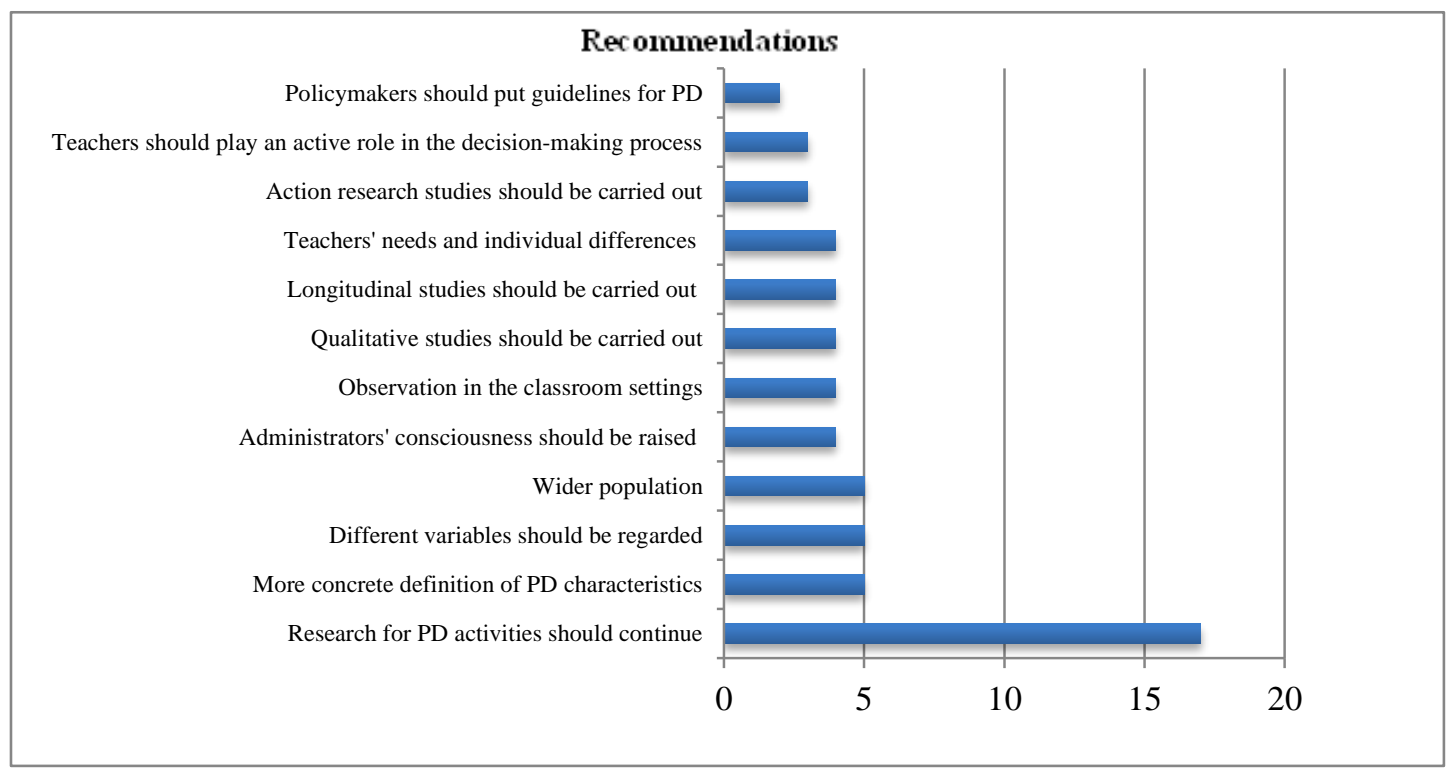

Figure 14. The distribution of studies carried out between 2005 and 2015 on teachers' professional development with regard to the recommendations

Researchers in 17 studies recommended that research concerning teachers' professional development should continue, as it is seen in Figure 14. In addition, they recommended to make a more concrete definition of professional development and to take different variables into consideration in further studies. Wider population, longer period of study, doing action research, and observation in classroom settings were other recommendations. Last but not least, researchers recommended that administrators should be more conscious about teachers' professional development and teachers should play an active role in decision-making process.

\section{Discussion}

This research examines the studies on teachers' professional development from various aspects. Also, it provides descriptive information about publication types, language, years of publication, research designs, data collection techniques, data collection tools, the number of sources of data, the sample and the sample size, the analysis type, the average number of participants, and the areas of study, findings, and recommendations. For each question, the findings are discussed. And, there are recommendations for the future researchers at the end of the study.

The findings indicated that the number of doctoral dissertations was more than master theses'. The closing decade of the last century was a threshold for the field of education as it became obvious that teachers needed guidance for the sustainability of their professional development and it was recognized that schools were the most convenient sites to continue their professional development (Banks, Mayes, Oaks \& Sutton, 2012). Therefore, many studies were conducted in order to figure out the components and dynamics of this process. Rollett (2012) pointed out that these studies were carried out in an attempt to explain or identify the values that entered into teachers' thinking process and the way in which they evaluated themselves. In this framework, it can be argued that there were mostly doctoral dissertations as they could depict the picture of professional development in a more comprehensive and vivid way.

According to the results of the publication language of the studies, it was revealed that English was the language of $82 \%$ of the studies. The reason for this might be the desire to introduce the studies to the international literature and to increase the possibility of being read. In addition, most of the master theses and doctoral dissertations were found through the ProQuest database, which increased the accessibility of English publications. Nevertheless, when the publications were compared for their language, Turkish was the dominant one in Turkish National Thesis Centre.

Of the 60 studies on teachers' professional development, 20 of them were conducted in the years 2013-2014. This indicated that professional development has become a hot issue recently, which increased the number of studies in the last years. Guskey (2000) pointed out that professional development was an on-going, job-embedded process in which there were learning opportunities for teachers every day. This point of view reflects the notion of a teacher, who learns continuously and seriously (Schoenfeld, 2011). The recognition about teachers' learning every day from their peers and their students by reflecting and talking about their practices led to emergence of many studies in recent years (Roesken, 2011). In this sense, the second decade of the $21^{\text {st }}$ century has been a milieu about the emergence of a new field of study - teachers' professional development. 
The findings of the study indicated that the most frequently used research design was qualitative research design. Qualitative research design helps researchers to be a part of the setting they observe and provides them with natural, interpretable, and meaningful data (Denzin \& Lincoln, 2005). In qualitative research, the focus of the researcher is on the process, rather than the product and s/he is the primary instrument of data. As there is an inductive process in qualitative research and there is complex way of analyzing data, the findings are enriched and descriptive (Merriam, 2009). In this respect, the reason why qualitative research was instrumented in most of the studies could be that the researchers desired to develop a sense and to probe deep into dynamics of professional development. In this way, the researchers might have felt that they would acquire more promising information to improve the profession of teaching and make strong associations with the stakeholders. When the qualitative research studies were examined in detail, it was seen that the most frequently encountered study was case study.

Another important finding was that the most frequently used data collection technique was the interview, which was used in 29 studies. As a qualitative technique, the interview provides the researcher with the direct source of data. It helps to collect data about the issues about which the researcher cannot gain insight through observation or document analysis. Moreover, it helps to obtain multiple perspectives about a particular topic (Stake, 2010). The interview is an appropriate data collection technique for the interviewees, who can easily share their opinions without hesitation and it ensures the variety of data (Creswell, 2012). Although document analysis and observation techniques were also used in the analyzed studies, the primary technique was the interview. Within this scope, it can be said that the researchers preferred to instrument the interview in their studies so that they could gain deeper and primary insight about the aspects they were doing research.

Findings related to the data collection tools showed that the most frequently used data collection tool was the survey, which was used in 19 studies. Academic achievement scores were used only in one dissertation and test/quiz was instrumented in two studies. Creswell (2012) stated as the findings should be expressed in numerical values, quantitative research is preferred. On the other hand, qualitative studies are conducted in their natural environment in an inferential design and the results of them are more accurate (Silverman, 2010). Although the survey was the most frequently used data collection tool, the results obtained from the content analysis indicated that the most frequently used research design was qualitative research design. Thanks to this, it is possible to say that the studies analyzed provided opportunities to make a deeper evaluation of teachers' professional development. According to Souto et al. (2015), mixed studies are ones in which both qualitative and quantitative data are used in a single study. Their aims are to verify all data sources so as to see whether it is possible to transform the results into one another. Yet, it is seen that there is limited amount of mixed study conducted on teachers' professional development. Thus, it is possible to suggest that mixed studies should be encouraged to describe the data in multiple ways.

Another finding was that one source of data was used in 20 studies; two sources of data were used in 18 studies and three or more sources of data were used in 22 studies. When they were compared, it can easily be said that there was a balanced distribution among the sources of data. As each study has its own dynamics and the research process, the source of data depends on the structure of the study and required conditions to comply with. However, as Patton (2015) implies, it is important not to give rise to the misconception that different data sources are instrumented in order to verify that the same result is yielded from different sources of data. It is mainly due to the fact that multiple sources of data make the comparison and crosscheck of the findings possible through triangulation (Merriam, 2009). It also helps to systematize the research process through the instrumentation of different data sources to answer the research questions (Mills, 2011, Yin, 2011).

Another important finding was that the most frequently used sample type was teacher. Although administrators and students were also referred to as sample in some of the studies, teachers were the basis for all the studies that were examined. Teachers have a significant impact on the learning of students. In parallel with this situation, their professional development will have an impact on student achievement (Darling-Hammond, 2012). As the issues such as the relationship between teacher and students' success, teachers' receiving administrative support or interaction with their colleagues have an effect on professional development, teachers may be accepted as the basis sample for all studies.

The most frequently encountered sample size was 0-30. The rationale behind this finding might be the nature of qualitative research studies. According to Patton (2015), the sample size range from a single participant to hundreds thanks to the advances in qualitative data management software programs. However, 20-30 participants are commonly included in most qualitative studies. As Merriam (2009) emphasized, the size of the sample depends on the research questions to be answered and the data to be collected. In this vein, the researchers within the scope of this study might have preferred to study with smaller samples in order to explore the issues in a deeper and thorough way.

When the finding about the analysis types were examined, it was found out that descriptive and qualitative analyses 
were the most frequently used ones in the studies, which were followed by predictive analysis. There were also some studies that were carried out with the combination of two or more analysis types. It is worth accenting the point that the initial purpose in a study is to uncover the hidden facts through the instrumentation of the appropriate analysis technique (Creswell, 2012). Therefore, the analysis type chosen, and especially the qualitative data analysis, helps the researcher to create patterns and themes while the data is digitized in quantitative studies (Glesne, 2012). In this scope, the publications within the framework of this study were mostly descriptive although there were some qualitative and predictive studies, as well. This might stem from the fact that the researchers might have desired to depict a picture of what they were searching for through utilizing the numbers. Needless to say, the number of qualitative studies was not less than the descriptive ones as the qualitative research design was the most frequently used research design.

Findings about the participant numbers in the studies demonstrated that 78 participants on average took part in the studies while the minimum number was one and the maximum number was 1341 . As stated above, the size and the number of participants are totally associated with the purpose and the research questions of a study. However, it is important to emphasize that quality interaction is an important parameter to obtain comprehensive and meaningful data in the studies, as it was also mentioned by Yildirim and Simsek (2008).

The most frequently studied area was professional learning communities with total number 16 studies. Many research (Benedict, 2014; Gokmen, 2014; Grado, 2014; Orlovsky, 2014; Spollen-LaRaia, 2013) conducted on the subject of student achievement and school applications demonstrated the importance of the teachers' cooperation with their peers in order to improve the students' learning skills. The studies that have been conducted over the years have brought new and different perspectives about teachers' coming together in a community and sharing their ideas and knowledge with each other. Therefore, this finding may be associated with this very condition.

One of the most frequently mentioned finding in the studies was that professional development activities had positive effects on teachers' professional development and improved teacher practice. One of the most important components of professional development is to become a member of a team in the workplace. As Glathorn (1987) stated, this helps to create 'a professional dialogue' among the teachers and meet on a regular basis. It is also crucial for gathering fruitful results on students' side, about both learning process and academic achievement. According to DuFour (2004), teachers' collaboration to improve classroom practices helps teachers to answer the questions in their minds as a whole team and this situation has significant effects on students' achievement. Furthermore, it is important that administrators have supportive attitudes throughout the professional development process and activities about professional development are chosen by taking teachers' needs into account. Carl (2009) pointed out that authorizing teachers systematically in the decision making process is crucial for teaching, professional collaboration and professional development.

Recommendations parts of the studies demonstrated that there is a growing need for research about professional development activities. Teachers like being part of professional teams on condition that they get fruitful results through collaborative teamwork (Brown, 2004) and this is among the features of an efficient professional development program (Garet et al., 2001). However, as recommendations point out, there are some ambiguities about defining professional development components in a more clear way. To solve this problem, professional development activities and roles can be determined through administrative support and collaborative work by taking students' needs into account (Yurtseven, 2016). Teachers should occupy a fundamental role in making decisions and identifying the needs, which should be done through considering their personal preferences. Wiggins and McTighe (2007) emphasized the importance of this issue in the following way:

"The idea of a school has no meaning if each teacher, even a hardworking and highly qualified one, is free to teach and assess as he wishes. The whole point of an institution with a mission is that, regardless of our differences, we are all obligated to work to cause some agreed-upon effects, in a coherent and coordinated manner. By being a teacher in a school or a college, we agree to agree about some fundamental ends and means. And working collaboratively (and selflessly) to achieve those common goals characterizes true professionalism" (p.27).

Last but not least, studies showed that observation in the classroom is an important parameter in determining the relationship between professional development and classroom practices. As Saunders (2014) stated, one of the main criterion for the efficiency of professional development programs is the application of the knowledge in the classroom appropriately. This will also help practitioners to understand whether these have an effect on student achievement (Darling-Hammond, 2012).

In conclusion, the current study had the purpose of analyzing the 60 studies between the years 2005-2015 and determined the tendencies within the scope of the publication type, the language, the year of publication, the research design, data collection techniques, data collection tools, the number of sources of data, the sample, the analysis type, the average number of participants, the areas of study, the findings and the recommendations. The following recommendations can be made in the light of the current study: 
1. When the qualitative studies in the scope of this study were examined, it was seen that case study was the most frequently used qualitative research design. It can be recommended that more action research studies be carried out to gain more insights about the problems teachers face in their professional lives.

2. When the studies in the scope of this study were examined, it was seen that the interview was the most frequently used technique. In the future, more studies utilizing the document analysis or the observation can be carried out.

3. As a data collection tool, students' achievement scores can be used more in order to find out the relationship between teachers' professional development and students' achievement in the future.

4. Different stakeholders can be included in the studies in order to analyze their share in teachers' professional development.

5. Different aspects of professional development (e.g. classroom teaching practices, professional development type and duration etc.) can be taken into consideration in the future so that different dimension can be illuminated.

6. Teachers should play an active role about determining the type of professional development activities and making decisions at the school level.

\section{References}

Banks, F., Mayes, A. S., Oakes, M., \& Sutton, D. (2012). Teaching early professional development. In Banks, F. \& Mayes, A. S. (Eds.), Early professional development for teachers (1-11). London: David Fulton Publishers.

Berg, B. L., \& Lune, H. (2012). Qualitative research methods for the social sciences (8th ed.). Boston, MA: Pearson.

Birman, B., Desimone, G. M., \& Porter, A. (2000). Designing professional development that works. Educational Leadership, 57(8), 28-33

Blandford, S. (2000). Managing professional development in schools. London: Routledge.

Brown, J. L. (2004). Making the most of understanding by design. USA: Association for Supervision andCurriculum Development.

Carl, A. E. (2009). Teacher empowerment through curriculum development: Theory into practice. South Africa: Juta and Company Ltd.

Creswell, J. W. (2012). Research design: Qualitative, quantitative, and mixed methods approaches. USA: Pearson Education.

Darling-Hammond, L., \& McLaughlin, M. W. (1995). Policies that support professional development in an era of reform. Phi Delta Kappan, 76(8), 597-604.

Darling-Hammond, L. (2012). Powerful teacher education: Lessons from exemplary programs. USA: John Wiley \& Sons, Inc.

Denzin, N. K., \& Lincoln, Y. S. (2005). The sage handbook of qualitative research. California: SAGE Publications Ltd.

Desimone, L. (2009). Improving impact studies of teachers' professional development: Toward better conceptualizations and measures. Educational Researcher, $38(3)$, http://dx.doi.org/10.3102/0013189X08331140

Diaz, M. G. (2004). Teacher-centered professional development. Alexandria, VA: ASCD.

DuFour, R. (2004). What is a professional learning community? School as Learning Communities, 61(8), 6-11.

Garet, M., Porter, A., Desimone, L., Birman, B., \& Yoon, K. (2001). What makes professional development effective? Analysis of a national sample of teachers. American Education Research Journal, 38(4), 915-945. http://dx.doi.org/10.3102/00028312038004915

Glathorn, A. A. (1987). Cooperative professional development: Peer-centered options for teacher growth. Educational Leadership, 45(3), 31-35.

Glesne, C. (2012). Nitel arastirmaya giris. (In. Ersoy, A., \& Yalcinoglu, P., Trans.) Ankara: Ani Publishing. (Original work published 2011).

Guskey, T. R. (2000). Evaluating professional development. California: Corwin Press, Inc.

Ingvarson, L., Meiers, M., \& Beavis, A. (2005). Factors affecting the impact of professional development nprograms on teachers' knowledge, practice, student outcomes \& efficacy. Education Policy Analysis Archives, 13(10). http://dx.doi.org/10.14507/epaa.v13n10.2005

Joyce, B., \& Showers, B. (2002). Student achievement through staff development (3rd ed.). Alexandria, VA: 
Association for Supervision and Curriculum Development.

Krippendorff, K. (2004). Content analysis: An introduction to its methodology (2nd ed.). Newbury Park, CA: SAGE Publications Ltd.

Lieberman, A., \& Pointer, M. D. (2008). Teacher learning: The key to education reform. Journal of Teacher Education, 59(3), 226-234. http://dx.doi.org/10.1177/0022487108317020

Merriam, S. B. (2009). Qualitative research: A guide to design and implementation. San Francisco: Jossey-Bass.

Mills, G. (2011). Action research: A guide for the teacher researcher. USA: Pearson Education, Inc.

National Board for Professional Teaching Standards. (2002). Moving education forward through National Board Certification [Brochure]. Arlington, VA.

Nicholls, G. (2001). Professional Development in Higher Education. New Dimensions and Directions. Kogan Page, London.

Patton, M. C. (2015). Qualitative research \& evaluation methods. USA: SAGE Publications, Inc.

Richards, J. C., \& Farrell, T. S. C. (2005). Professional development for language teachers: Strategies for teacher learning. New York: Cambridge University Press. http://dx.doi.org/10.1017/CBO9780511667237

Roesken, B. (2011). Hidden dimensions in the professional development of mathematics teachers: In-service education for and with teachers. Rotterdam: Sense Publishers. http://dx.doi.org/10.1007/978-94-6091-433-1

Rollett, B. A. (2012). How do expert teachers view themselves? In Banks, F. \& Mayes, A. S. (Eds.), Early professional development for teachers (27-40). London: David Fulton Publishers.

Saunders, R. (2014). Effectiveness of research-based teacher professional development. Australian Journal of Teacher Education, 39(4), 166-184. http://dx.doi.org/10.14221/ajte.2014v39n4.10

Schoenfeld, A. H. (2011). Toward professional development for teachers grounded in a theory of decision making. ZDM Mathematics Education, 43, 457-469. http://dx.doi.org/10.1007/s11858-011-0307-8

Shulman, L., \& Sparks, D. (1992). Merging content knowledge and pedagogy: An interview with Lee Shulman. Journal of Staff Development, 13(1), 14-16.

Silverman, D. (2010). Doing qualitative research: A practical handbook. London: SAGE Publications Ltd.

Souto, R., Khanassov, V., Hong, Q. N., Bush, P., Vedel, I., \& Pluye, P. (2015). Systematic mixed studies reviews: Updating results on the reliability and efficiency of the Mixed Methods Appraisal Tool. International Journal of Nursing Studies, 52(1), 500-501. http://dx.doi.org/10.1016/j.ijnurstu.2014.08.010

Stake, R. E. (2010). Qualitative research: Studying how things work. USA: The Guilford Press.

Wiggins, G., \& McTighe, J. (2007). Schooling by design: Mission, action, and achievement. USA: Association for Supervision and Curriculum Development.

Yidirim, A., \& Simsek, H. (2008). Sosyal bilimlerde nitel arastirma yontemleri (7th ed.). Ankara: Seckin Yayincilik.

Yildirim, R., \& Seker, M. (2013). Community of practice: An investigation into its impact on ELT students' personal and professional development, Cukurova Universitesi Sosyal Bilimler Enstitusu Dergisi, 2(22), 365-382.

Yin, R. K. (2011). Qualitative research from start to finish. USA: The Guilford Press.

Yurtseven, N. (2016). Yabanci dil ogretiminde eylem arastirmasina dayali UbD (anlamaya dayali tasarim) uygulamalarinin ogretmenler ve ogrenciler uzerindeki yansimalarinin incelenmesi (Doctoral Dissertation, Yildiz Technical University, Turkey). 


\section{Appendix}

\begin{tabular}{|c|c|}
\hline Master Theses and Doctoral Dissertations Investigated within the Content Analysis & $\begin{array}{l}\text { Publication } \\
\text { Date }\end{array}$ \\
\hline $\begin{array}{l}\text { Adams, R. D. (2010). A case study of professional development in an online environment: The } \\
\text { experiences of a group of elementary teachers (Doctoral Dissertation, New Mexico State } \\
\text { University). }\end{array}$ & 2010 \\
\hline $\begin{array}{l}\text { Allen, L. S. (2009). Differentiating professional development for teachers: How teachers } \quad \text { develop and } \\
\text { implement professional growth plans (Doctoral Dissertation, University of Kentucky). }\end{array}$ & 2009 \\
\hline $\begin{array}{l}\text { Ateskan, A. (2008). Online professional development program for science teachers: A case study } \\
\text { (Doctoral Dissertation, Middle East Technical University). }\end{array}$ & 2008 \\
\hline $\begin{array}{l}\text { Balta, N. (2014). The effect of a professional development program on physics teachers' knowledge } \\
\text { and their students' achievement in modern physics unit (Doctoral } \quad \text { Dissertation, Middle East Technical } \\
\text { University). }\end{array}$ & 2014 \\
\hline $\begin{array}{l}\text { Bas, S. (2013). An investigation of teachers' noticing of students' mathematical thinking in the context } \\
\text { of a professional development program (Doctoral Dissertation, Middle EastTechnical University). }\end{array}$ & 2013 \\
\hline $\begin{array}{l}\text { Bayram, D. (2010). Turkiye, ABD, Japonya, Ingiltere ve Avustralya'da fen ve fizik ogretmenlerine } \\
\text { yonelik mesleki gelisim programlarinin karsilastirilmasi (Doctoral Dissertation, Ankara University). }\end{array}$ & 2010 \\
\hline $\begin{array}{l}\text { Benedict, C. M. (2014). Professional learning community: Increasing efficacy for student } \quad \text { success } \\
\text { (Doctoral Dissertation, The State University of New Jersey). }\end{array}$ & 2014 \\
\hline $\begin{array}{l}\text { Brundage, S. E. (2005). Factors related to the pursuance of professional development by elementary } \\
\text { school teachers (Doctoral Dissertation, Binghamton University). }\end{array}$ & 2005 \\
\hline $\begin{array}{l}\text { Byrnes, K. A. (2009). Investigating teacher attitudes about action research as a professional development } \\
\text { tool (Doctoral Dissertation, Hofstra University). }\end{array}$ & 2009 \\
\hline $\begin{array}{l}\text { Cournoyer, A. B. (2014). Building language educators: the implications of case-based pedagogy using } \\
\text { practicum-based student-teacher-generated cases for pre-service language teacher education } \\
\text { (Doctoral Dissertation, Boston University). }\end{array}$ & 2014 \\
\hline $\begin{array}{l}\text { Caglar, E. (2013). A qualitative study of peer observation of teaching as a job-embedded } \\
\text { development tool (Master's Thesis, Middle East Technical University). }\end{array}$ & 2013 \\
\hline $\begin{array}{l}\text { Celik, H. (2011). Teacher portfolio: Effects and implications for English language teachers' competencies } \\
\text { and professional development (Master's Thesis, Canakkale Onsekiz Mart University). }\end{array}$ & 2011 \\
\hline $\begin{array}{l}\text { Cetin, M. (2013). An action research on e-mentoring: A supplemental tool for professional development } \\
\text { of EFL teachers working at MNE schools (Master's Thesis, CagUniversity). }\end{array}$ & 2013 \\
\hline $\begin{array}{l}\text { Deirdre, S. L. (2011). Literacy coaching: Is it a link to transforming teacher collaboration, school } \\
\text { culture, and student achievement? (Doctoral Dissertation, College of Saint Elizabeth). }\end{array}$ & 2011 \\
\hline $\begin{array}{l}\text { Diemert, K. M. (2014). Putting professional development into practice: how teachers process, } \\
\text { implement, and disseminate specialized knowledge of standards (Doctoral Dissertation,Montana } \\
\text { State University). }\end{array}$ & 2014 \\
\hline $\begin{array}{l}\text { Durmus, E. (2013). Ogretmenlerin mesleki gelisimine yonelik goruslerinin incelenmesi (Master's Thesis, } \\
\text { Celal Bayar Univeristy). }\end{array}$ & 2013 \\
\hline $\begin{array}{l}\text { Eksi, G. (2010). An assessment of the professional development needs of English language instructors } \\
\text { working at a state university (Master's Thesis, Middle East Technical University). }\end{array}$ & 2010 \\
\hline $\begin{array}{l}\text { Elci, A. (2012). Faculty beliefs and needs: Opening the gate to ICT-based professional development } \\
\text { in teaching and learning (Doctoral Dissertation, Eastern Mediterranean University). }\end{array}$ & 2012 \\
\hline $\begin{array}{l}\text { Emig, J. M. (2006). The effects of professional development in literacy on selected teachers: A } \\
\text { cross-case analysis (Doctoral Dissertation, Boston University). }\end{array}$ & 2006 \\
\hline $\begin{array}{l}\text { Esendemir, O. (2011). Matematiksel problem cozme ve ust bilis uzerine hazirlanan bir mesleki } \\
\text { programi ve bu programin etkililigi (Master's Thesis, Gaziantep Univeristy). }\end{array}$ & 2011 \\
\hline $\begin{array}{l}\text { Gargus, G. V. (2006). Teachers' professional development needs and current practices at the } \\
\text { Alexander Science Centre School (Doctoral Dissertation, University of Southern California). }\end{array}$ & 2006 \\
\hline $\begin{array}{l}\text { Gencer, A. S. (2008). Professional development of pre-service biology teachers through } \\
\text { thinking (Doctoral Dissertation, Middle East Technical University). }\end{array}$ & 2008 \\
\hline $\begin{array}{l}\text { Good, L. (2009). Using professional development to improve elementary teachers' mathematics } \\
\text { teaching: as action research study (Doctoral Dissertation, University of Rochester). }\end{array}$ & 2009 o \\
\hline $\begin{array}{l}\text { Grado, C. (2014). Key strategies for designing professional development for teachers of blended high } \\
\text { school courses as perceived by California high school principals (Doctoral Dissertation, } \\
\text { University of La Verne). }\end{array}$ & 2014 \\
\hline
\end{tabular}


Hawkins, D. L. (2010). University Of South Carolina's elementary professional development school 2010

partnerships: Conditions influencing professional development in teachers (Doctoral Dissertation, University Of South Carolina).

Iyidogan, F. (2011). Personal factors affecting experienced English teachers' decisionswhether or not to engage in professional development activities (Master's Thesis, Bilkent University).

Jackson, A. S. (2006). Teacher perceptions of professional development in Buncombe County Schools (Doctoral Dissertation, Western Carolina University).

Kabadayi, B. (2013). A study on professional development needs of EFL instructors working at a foundation university (Master's Thesis, Cag University).

Kahraman, M. (2012). Bilisim teknolojileri ogretmen adaylarinin mesleki gelisiminde e-mentorluk (Doctoral Dissertation, Anadolu Univeristy).

Kanadli, S. (2012). Ogretmenlere yonelik hazirlanan bir mesleki gelisim programinin etkililiginin incelenmesi (Doctoral Dissertation, Gaziantep Univeristy).

Karamahmutoglu, A. (2014). Ilkokul ve ortaokul yoneticilerinin liderlik davranislarinin ogretmenlerin mesleki gelisimine etkisi (Master's Thesis, Yeditepe Univeristy).

Karli, M. K. (2013). Turkiye egitim sisteminde bir alternatif hizmet ici egitim modeli olarak ORAV-Ogretmenin Siniri Yok Projesi (Master's Thesis, Yeditepe Univeristy).

Kaya, V. H. (2011). Fen ve teknoloji ogretmenlerinin profesyonel gelisimlerini etkileyen etkenlere yonelik gorusler (Master's Thesis, Ahi Evran Univeristy).

Kirazlar, C. (2007). An investigation into the professional development of primary school English language teachers: The effects of keeping diaries on teacher reflection and attitudes towards teaching (Master's Thesis, Canakkale Onsekiz Mart University).

Kokoc, M. (2012). Karma mesleki gelisim programi surecinde ilkogretim sinif ogretmenlerinin teknolojik pedagojik alan bilgisi deneyimleri uzerine bir calisma (Master's Thesis, Karadeniz

Teknik University).

Korkmaz, T. (2015). In-service ELT Teachers' first year with reference to mentor teachers and professional development (Master's Thesis, Ufuk University).

Korucu, S. (2011). The use of action research as a model in the professional development of an English teacher: A case study (Master's Thesis, Selcuk University).

Kulavuz-Onal, D. (2013). English language teachers' learning to teach with technology through participation in an online community of practice: An ethnography of web heads in action (Doctoral Dissertation, University of South Florida).

Lee, H. S. (2014). The intersection between professional development and professional learning communities: working towards improving the educational experiences of English learners (Doctoral Dissertation, University of Maryland).

Mannino, G. (2014). Professional development: Identifying effective instructional coaching activities (Doctoral Dissertation, Lamar University).

McFarland, E. S. (2014). Teachers' Perceptions of Professional Development: What do teachers really want that makes them willing to change professional practice? (Doctoral Dissertation, North Carolina State University).

Meagher, T. (2011). An investigation of the relationships of teacher professional development, teacher job satisfaction, and teacher working conditions (Doctoral Dissertation, Loyola University).

Mutlu, N. (2012). The design and development of an online professional development material for science and technology teachers on assessment and evaluation (Doctoral Dissertation, Middle East Technical University).

Muyan, E. (2013). A case study on ELT teachers' perceptions towards professional development activities (Master's Thesis, Cag University).

Neuberger, J. A. (2010). Fostering effective mathematics teaching: Professional coaching and Jersey). teachers' instructional practices and beliefs (Doctoral Dissertation, The State University of New

Orlovsky, C. B. (2014). Effects of professional development on the mathematical instructional practices of elementary school teachers: An action research study (Doctoral Dissertation,

Capella University).

Onkol, P. E. (2011). Perceptions of professional development at Bilkent University faculty academic English program (Doctoral Dissertation, Middle East Technical University).

Oz, A. (2012). Milli Egitim Bakanligi bunyesinde duzenlenen hizmet ici egitimlerin din kulturu ve ve Marmara University). 
Ozbek, M. (2014). The profile and the continuous professional development activity choice of $\quad$ English 2014

language teachers and the factors influencing their choice (Master's Thesis, Cag University).

Ozcalli, S. (2007). Possible effects of in-service education on EFL teachers' professional development 2007

in terms of teacher efficacy and reflective thinking (Master's Thesis, Bogazici University).

Qi, L. (2012). The role of Chinese normal universities in the professional development of teachers 2012

(Doctoral Dissertation, University of Toronto).

Rendos, M. S. (2005). Perceptions of teachers and administrators of factors that motivate teachers to 2005 actively engage in professional development (Doctoral Dissertation, The Pennsylvania State University).

Rosen, M. L. (2014). Teacher leaders as professional development providers: A case study (Doctoral

Dissertation, The State University of New Jersey).

Sadic, F. (2015). A comparative study on EFL instructors' attitudes towards professional development activities in state and foundation universities (Master's Thesis, Cag University).

Scherrod, G. (2014). Perceptions of secondary school teachers and administrators on effective professional development programs (Doctoral Dissertation, Walden University).

Suleymangil, M. (2013). Sinif ici ogretim etkinligi gelistirme ve kullanma calismalarinin sinif ogretmenlerinin mesleki gelisimleri uzerindeki rolu (Master's Thesis, Adnan Menderes University).

Tas, S. (2014). The impact of teacher portfolios on promoting professional development: A case study at Namik Kemal University (Master's Thesis, Trakya University).

Yenmez, A. A. (2012). An investigation of in-service secondary mathematics teachers evolving knowledge through professional development activities based on modelling perspective (Doctoral

Dissertation, Middle East Technical University).

Yilmaz, B. N. (2012). Beliefs of members of an online community of practice on the effects of membership on teaching and professional development (Master's Thesis, Middle East Technical

University).

Yumsek, M. (2014). Professional development of pre-service English language teachers in line with the European Portfolio for student teachers of languages (EPOSTL) (Master's Thesis, Akdeniz University).

This work is licensed under a Creative Commons Attribution 3.0 License. 